\title{
Aplikasi Sistem Imuno-Probiosirkulasi pada Tambak Udang pola Tradisional Di Desa Jenu, Kabupaten Jenu
}

\section{Aplication of the Imuno-Probicirculation System in Traditional Shrimp Culture in Jenu Village, Tuban Region}

Sudarno, Gunanti Mahasri* dan Rahayu Kusdarwati.

Departemen Manajemen Kesehatan Ikan dan Budidaya Perairan, Fakultas Perikanan dan Kelautan, Universitas Airlangga, Surabaya

*mahasritot@gmail

\begin{abstract}
Abstrak
Udang galah (Penaeus monodon Fab) merupakan salah satu udang yang penting secara ekonomi, sampai tahun 1992 menjadi komoditi ekspor non migas yang paling penting dari sektor perikanan. Sejak akhir tahun 1993 sampai sekarang, tingkat kematian Penaeus monodon Fab relatif tinggi dan karena keadaan ini telah menyebabkan banyak tambak roboh sehingga produksi udang menurun secara dramatis dari tahun ke tahun. Kabupaten Jenu merupakan salah satu daerah Tuban yang memiliki potensi perikanan besar, terutama untuk kolam air pemecah gelombang, yang paling top sebagai kabupaten lainnya. Ada banyak kasus mati udang sampai sekarang. Tapi, agar $80 \%$ kolam pemecah air pecah dan tidak operasional. Tujuan dari kegiatan pelayanan masyarakat ini adalah menerapkan teknologi kultur udang Imuno-Probiokulasi dengan metode tradisional plus (SI-PBR), meningkatkan produksi udang di Kabupaten Jenu, Tuban, Jawa Timur. Metode yang digunakan dalam kegiatan ini adalah sosialisasi / konseling, perencanaan dan panduan penerapan teknologi SI-PBR dalam satu periode (tiga bulan). Hasil ini menunjukkan indikasi positif. Ada pengetahuan petani yang berhenti melalui sosialisasi, namun juga menerapkan teknologi budidaya udang. Ada juga yang menunjukkan bahwa model SI-PBR dapat menurunkan produksi udang dari 272,43 kg / ha menjadi 854,66 kg / ha, artinya meningkat 313\%. Kesimpulan dari kegiatan ini adalah model SI-PBR dapat meningkatkan produksi udang dan dapat diaplikasikan di daerah yang lebih luas di wilayah Tuban.
\end{abstract}

Kata kunci : udang galah, cloture, tradisional plus, Imuno-Probiosirculation and Production

\begin{abstract}
Tiger shrimp (Penaeus monodon Fab) is one of the economically important shrimp, until 1992 became the most important of non petroleum export commodity from fishery sector. Since the end of 1993 up to now, the Penaeus monodon Fab death level has been relatively high and due to this circumstance have been caused many ponds collapsed so that the shrimp production was dramatically declined for year by year. Jenu District is one of Tuban Region areas which have big fisheries potential, aspecially for the breakist water pond, that the topest as the other district. There are a lot of shrimp dead cases until now. But, so that $80 \%$ of breakist water pond were broken and not operational. The objective of this societies service activities is applicated a new shrimp culture technology Imuno-Probiocirculation System in traditional plus (SI-PBR), increaseses the shrimp production at Jenu District Region of Tuban, East Java. The method using in the activity were socialitation/counseling, dempond and guiding to application of the SI-PBR technology in one periode (three Months). This result showed that a positive indication. There was the knowledges of the farmer in ceases by socialization, it also applicated that technology in shrimp culture. There were also showed that the SI-PBR model can inceased the shrimp production from 272,43 kg/ha to 854,66 kg/ha, it means was increased $313 \%$. The conclution of this activity is the SI-PBR model can increased the shrimp production and can applicates in more larges area in Tuban Region.
\end{abstract}

Keywords: Tiger Shrimp, Clature, Traditional Plus, Imuno-Probiosirculation and Production 


\section{PENDAHULUAN}

Sejak awal tahun 1994 produksi udang windu ( Penaeus monodon Fab ) di Jawa Timur pada khususnya dan di Indonesia pada umumnya mengalami penurunan yang sangat drastis. Hal ini disebabkan karena terjadinya kasus kematian udang baik di tambak maupun hatchery, yang disebabkan karena adanya serangan penyakit, kualitas air yang menurun dan sudah tidak sesuainya teknologi yang digunakan. Akan tetapi udang windu masih diharapkan menjadi salah satu jenis udang laut yang mempunyai nilai ekonomis penting dan bergizi tinggi. Disamping itu juga diharapkan masih menjadi primadona andalan komoditas eksport non migas dari sektor perikanan. Akan tetapi sejak hingga sekarang produksi udang windu mengalami penurunan yang sangat drastis hingga tinggal sekitar 30\% tambak yang masih operasional dan selebihnya menjadi tambak yang tidak produktif dan rusak (idle) (DKP, 2001).

Tahun 2002 Udang Vannamei yang masuk ke Indonesia dengan harapan dapat menggantikan kedudukan udang windu, namun kenyataannya masih belum dapat diharapkan dan belum dapat mengembalikan kondisi udang seperti masa jayanya udang windu. Tahun 1997 dan 1998 produksi udang windu baik benur maupun ukuran konsumsi terjadi peningkatan dari $<10 \%$ hingga mencapai $30 \%$ dengan harga jual mencapai Rp.170.000,- per kg size 30 ekor (Kompas, 1998). Untuk selanjutnya kondisi produktivitas udang windu menunjukkan grafik yang naik turun, dan berbagai trobosan untuk mengatasi sudah banyak upaya yang dilakukan (Taslihan, dkk. 2005).

Pemerintah sudah banyak mengusahakan revitalisasi tambak udang windu sejak awal tahun 2002 dengan berbagai teknologi yang diterapkan. Bahkan Pemerintah sudah mengesahkan adanya pengganti jenis udang ini dengan jenis udang lain yaitu udang Vanamai dan
Steilirostris. Akan tetapi belum dapat menggeser kedudukan udang windu. Produksi udang vannamei sampai saat ini baru mencapai $40-50 \%$ dari target produksi. Keadaan ini mengakibatkan bahwa sampai saat ini pemenuhan kebutuhan udang untuk konsumsi masih merupakan masalah besar bagi negara Indonesia. Upaya memulihkan nilai ekonomis udang windu masih perlu dipikirkan dan mendapatkan perhatian khusus (Syarif dan Faisol, 2006). Ditinjau dari sisi ekonomis harga udang vannamei jauh lebih murah jika dibandingkan dengan harga udang windu, sehingga produksi udang windu sampai sekarang masih sangat perlu ditingkatkan. Bertitik tolak dari kondisi tersebut maka sangat perlu dilakukan perbaikan-perbaikan metode (teknologi) pada pembesaran (budidaya) udang windu tersebut di tambak terutama tambak tradisional.

Permasalahan utama yang menghambat pada upaya revitaslisasi tambak udang, di Indonesia pada umumnya dan Jawa Timur pada khususnya adalah lambat atau rendahnya pertumbuhan dan tingginya kematian udang di tambak akibat penurunan kualitas air serta serangan penyakit/patogen. Serangan penyakit virus bercak putih atau dikenal dengan "white spot" (WSSV) merupakan kendala utama dan menjadi permasalahan yang serius pada kegiatan budidaya udang. Apalagi budidaya tambak udang tradisional umumnya mengandalkan dan sangat tergantung pada kondisi pasang surut air laut.

$$
\text { Kabupaten Tuban merupakan }
$$

sebuah Kabupaten yang mempunyai wilayah kerja dibagi menjadi empat dengan 22 kecamatan. Potensi perikanan di Kabupaten ini termasuk mempunyai potensi yang besar, dengan luas tambak 19.729,236 Ha, dengan jumlah petani tambak sekitar 14.292 orang. Produksi usaha budidaya ikan dan udang di tambak adalah sekitar 17.596,235 ton/tahun. Kondisi yang demikian menjadikan Tuban menduduki peringkat II (Dua) pengekspor 
udang Indonesia. Akan tetapi sejak akhir tahun 1993 hingga sekarang produksi udang Tuban menurun drastis hingga 70\%, karena adanya kasus kematian udang yang disebabkan karena adanya serangan penyakit dan menurunnya kualitas air. Akibat kasus kematian tersebut saat ini di Sidoarjo sudah tidak ada tambak intensif yang beroperasional dan hanya 20\% tambak semi intensif yang masih produksi. Selain itu hanya sekitar 40\% tambak tradisional yang opresianal. Hal ini dapat diartikan bahwa tambak idle di Tuban mencapai sekitar 60\% dari seluruh wilayah. Di beberapa desa di Kabupaten Tuban yang mempunyai arti penting dan mendukung perekonomian negara dari bidang perikanan, akan tetapi terdapat 2 desa yaitu Desa Jenu, Kecamatan Jenu dan Palang. Luas pertambakan di desa tersebut rata-rata mencapai $406.336 \mathrm{Ha}$, yang potensial untuk budidaya udang, khususnya udang windu, dengan produksi mencapai 18. 788 ton/tahun.

Upaya revitalisasi tambak idle oleh Pemerintah Pusat maupun Tuban sudah banyak dilakukan dan pada tahun 1998 di Kecamatan Jenu produksinya mencapai 5.731, 48 ton dari seluruh luas tambak 6.164,00 hektar. Nilai ini menempati urutan pertama atau tertinggi dibandingkan dengan hasil tambak dari kecamatan lain di Tuban (Dinas Perikanan Kabupaten Tuban). Akan tetapi nilai ini masih merupakan nilai yang rendah jika dibandingkan tahun sebelum terjadi kasus kematian. Produksi tahu 2007 mencapai 7.654, 13 ton lebih rendah jika dibandingkan tahun 1992 (sebelum terjadi kasus kematian udang) yang mencapai 14 , 34 ton/hektar per tahun. Di sisi lain para petambak (pendega) di Desa Jenu, Kecamatan Jenu, Kabupaten Tuban umumnya termasuk dalam kelas ekonomi rendah dan mempunyai tingkat pendidikan yang sebagian besar hanya tamat tingkat Sekolah Dasar (SD) (Data Statistik DKP Tuban, 2005). Hal ini menjadikan kendala dalam usaha budidaya udang, karena teknologi yang digunakan hanya mengandalkan teknologi yang turun temurun dari nenek moyangnya.

Bertitik tolak dari hal tersebut maka CV PUTRI MANDIRI GRUP dan C.V. ALAMINDO merupakan suatu industri kecil yang bergerak dalam bidang budidaya udang di tambak dan pembenihan udang windu skala rumah tangga. Kantor terletak Di Jalan Raya Beringin, Tulangan, Sidoarjo Jawa Timur. Modal yang digunakan untuk operasional tambak, merupakan iuran dari beberapa petani tambak kecil, yang sampai sekarang jumlah petambak udang yang bergabung mencapai 18 pemilik tambak dengan berbeda-beda besar investasinya. Tambak yang bergabung ini terletak di berbagai daerah di Jawa Timur yang meliputi : Kabupaten Sidoarjo (Sawoan dan Kedung Peluk, Kec. Candi), Pasuruan, Gersik dan Madura (Sampang), Tuban. Luas tambak dari 18 pemilik tersebut mencapai 36 Hektar. Produksi udang dari tambak tradisional milik CV. Putri Mandiri Grup dalam ukuran konsumsi saat ini hanya mencapai $800 \mathrm{~kg} / \mathrm{Ha}$ per tahun. Produksi ini masih terlalu kecil dalam skala tambak tradisional yang dapat mencapai 2,5 ton /Ha per tahun. Masih rendahnya produksi ini antara lain disebabkan karena sudah tidak sesuainya teknologi yang digunakan, penyakit dan kualitas air. Kebanyakan teknologi yang digunakan adalah masih system tradisional sederhana. Kemudian mulai ditingkatkan menjadi system tradisional plus, akan tetapi metode ini hasil panennya masih belum dapat memenuhi target, sehingga petani yang bergabung ini masih memiliki penghasilan yang sangat rendah, dengan rata-rata penghasilan hanya mencapai 2,9 juta pada tiap periode panen yaitu selama 3 - 3,5 bulan. Berdasarkan keterangan tersebut, maka CV. Putri Mandiri Grup Sidoarjo memerlukan suatu teknologi budidaya udang yang mudah dilakukan dan murah biayanya, untuk meningkatkan hasil panen, sehingga meningkatkan 
penghasilan dan kesejahteraan petambak yang bergabung (anak asuh).

Penerapan teknologi budidaya yang tepat guna, praktis, mudah dan murah sangat diharapkan untuk revitalisasi tambak idle di Kabupaten Tuban khususnya di Kecamatan Jenu. Penggunaan Imunostimulan, Probiotik dari bakteri bersamaan dengan ikan bandeng sebagai biofilter (Probifilter) yang termasuk dalam system SI-PBR merupakan teknologi tepat guna yang diterapkan dalam budidaya udang baik windu maupun vannamei, dengan menggunakan probiotik, bio filter dan sirkulasi air tambak. Menurut Mahasri (1999, 2002) bahwa Probiotik merupakan bahan yang berisi berbagai jenis bakteri yang dapat berperan positif dalam menguraikan bahan organik di tambak dan membantu metabolisme bila dicampur pada pakan udang. Sedangkan biofilter yang dapat diperankan oleh ikan bandeng (Chanos chanos Forsk) atau rumput laut dapat digunakan untuk menyeimbangkan bio massa (plankton) di air tambak agar tetap dalam kondisi seimbang. Selanjutnya dikatakan bahwa sirkulasi air merupakan salah satu tindakkan yang mutlak harus dilaksanakan dalam kegiatan budidaya udang untuk mempertahankan kualitas air.

Penerapan teknologi Probiofilter ini akan didapatkan hasil panen udang yang berkualitas dan bebas penyakit. Air tambak akan tetap dalam kondisi yang berkualitas, sehingga penyakit tidak muncul selama budidaya dan udang dapat tumbuh dengan baik dan sehat. Di Thailand sistem Probiofilter ini sudah diterapkan pada tambak udang windu dan dapat meningkatkan produksi hingga 2 ton per hektar (Chifumi, et al., 2005), di China dapat meningkatkan tingkat kelangsungan hidup (SR) hingga 81\% dan di India dapat meningkatkan produksi hingga 3 kali jika dibandingkan dengan sistem budidaya intensif. Sistem ini merupakan gabungan antara penggunaan imunostimulan pada benih udang sebelum ditebar untuk meningkatkan daya tahan tubuh udang. Imunostimulan yang digunakan adalah adalah imunostimulan dari dinding sel bakteri, parasit dan virus.

Menurut Mahasri (2000), menyatakan bahwa aplikasi SI-PBR pada tambak tradisional plus dapat meningkatkan tingkat kelulushidupan (SR) udang windu di tambak hingga 86\%. Selanjutnya oleh Mahasri (2001), Chamratkhakool (1996) dan Subandriyo (2001) bahwa dengan filter biologis dari ikan bandeng dan rumput laut pada tambak tradisional plus dapat meningkatkan hasil panen hingga 82\%.

\section{Metode Penelitian}

Berdasarkan identifikasi permasalahan pada mitra, maka permasalah utama yang harus segera ditangani adalah: 1) Permasalahan tambak yang rusak dan tidak operasional, 2) Hasil Panen rendah, sehingga gulung tikar, 3) Penghasilan petambak yang sangat rendah dan 4) Rendahnya pengetahuan dan keterampilan dalam melaksanaka usaha tambak.

\section{Metode yang Ditawarkan}

Metode pelaksanaan kegiatan ini terdiri dari tiga tahap yaitu : (1) Tahap pembuatan petak SI-PBR dan petakan pemeliharaan udang, (2) Tahap penyuluhan dan pelatihan serta (3) Tahap penerapan budidaya udang di tambak tradisional dengan SI-PBR..

\section{Prosedur Kerja \\ Penerapan SI-PBR \\ Tahap pembuatan Petak SI-PBR.}

Pembuatan Pertak Resirkulasi dilakukan langsung di tambak milik CV. Putri Mandiri Grup. Proses pembuatannya meliputi : (1) Penyedian lahan dan petakan tambak, (2) Penyiapan dan pembuatan SIPBR sesuai dengan fungsinya, (3) Penyediaan probiotik dan imunostimulan.

\section{Tahap penyuluhan dan peragaan.}


Penyuluhan dan peragaan cara pembuatan petak SI-PBR dengan biofilter ikan bandeng dilakukan dengan mengunjungi petambak yang bergabung di CV-PMG di Desa Masaran, Kecamatan Banyuates, Kabupaten Sampang (door to door). Metode ini dilaksanakan dengan pertimbangan efektivitas dan efisiensi kerja tim pelaksana pengabdian kepada masyarakat dan kemudahan pihak khalayak sasaran untuk menerima pengetahuan tentang SI-PBR. Adapun materi penyuluhan meliputi tentang budidaya udang windu SI-PBR dengan biofilter ikan bandeng dan petak tandon serta patak pemeliharaan. Tahap peragaan secara langsung dilakukan di lokasi tambak sehingga khalayak sasaran dapat lebih memahami dan mengerti materi penyuluhan dengan baik sehingga dapat mengoperasikannya di lapangan. Disamping itu juga dilakukan peragaan tentang teknik imunisasi pada benih udang.

\section{Tahap Penerapan Budidaya Udang Dengan System SI-PBR.}

Pada tahap ini merupakan tahap penerapan langsung budidaya udang windu dengan Sistem SI-PBR di tambak. Tahap ini diawali dengan pengecekan ulang petakan SI-PBR dengan filter biologi yang digunakan adalah ikan bandeng. Penyediaan benih dilakukan oleh tim penyuluh, dalam hal ini tim penyuluh bersifat sebagai pembimbing selama satu siklus pemeliharaan udang yaitu kurang lebih selama 4 bulan. Selama masa pemeliharaan udang satu siklus, kegiatan yang dilakukan adalah melakukan pengontrolan terhadap petak sirkulasi, kualitas air dan kesehatan dan pertumbuhan udang sebagai data pendukung penilaian tingkat keberhasilan SI-PBR yang diterapkan.

\section{HASIL DAN PEMBAHASAN Penerapan SI-PBR}

Kegiatan ini merupakan kegiatan pengabdian kepada masyarakat yang menerapkan Sistem Imunobio-Sirkulasi (SI-PBR) yang merupakan teknologi tepat guna yang diterapkan dalam budidaya udang baik windu maupun vannamei, dengan menggunakan imunostimulan, bio filter dan sirkulasi air tambak. Menurut Mahasri (2007) mengatakan bahwa imunostimulan dari Zoothamnium penaei dapat meningkatkan tingkat kelulushidupan udang yang dipelihara dari 10 hingga $81 \%$. Sedangkan biofilter yang dapat diperankan oleh ikan bandeng (Chanos chanos Forsk) atau rumput laut dapat digunakan untuk menyeimbangkan bio massa (plankton) di air tambak agar tetap dalam kondisi seimbang. Selanjutnya dikatakan bahwa sirkulasi air merupakan salah satu tindakkan yang mutlak harus dilaksanakan dalam kegiatan budidaya udang untuk mempertahankan kualitas air.

Penerapan SI-PBR ini akan didapatkan hasil panen udang yang berkualitas dan bebas penyakit. Air tambak akan tetap dalam kondisi yang berkualitas, sehingga penyakit tidak muncul selama budidaya dan udang dapat tumbuh dengan baik dan sehat. Di Thailand biosirkulasi ini sudah diterapkan pada tambak udang windu dan dapat meningkatkan produksi hingga 2 ton per hektar (Chifumi, et al., 2005), di China dapat meningkatkan tingkat kelangsungan hidup (SR) hingga 81\% dan di India dapat meningkatkan produksi hingga 3 kali jika dibandingkan dengan sistem budidaya intensif. Menurut Mahasri (2000), menyatakan bahwa aplikasi SIBR pada tambak tradisional plus dapat meningkatkan tingkat kelulushidupan (SR) udang windu di tambak hingga 86\%.

Tahapan dari penerapan model tambak pola tradisional plus SI-PBR ini mencakup: penyediaan lahan dan konstruksi tambak, persiapan tambak, pembuatan petak tandon dan filter biologis, manajemen kualitas air, penyediaan benur, pemeliharaan udang, 
pemberantasan hama dan penyakit, pemanenan dan manajemen pasca panen.

\section{Konstruksi Tambak}

Konstruksi tambak dan tata letak tambak menyesuaikan keadaan yang ada di lokasi, sebab apabila harus merubah akan memerlukan waktu yang lama, sehingga di kawatirkan waktu penelitian tidak cukup. Bentuk petakan tambak yang digunakan untuk penerapan ini adalah empat persegi panjang sebanyak dua petak dengan luas masing-masing \pm 1.2 ha, kedalaman \pm 100 $\mathrm{cm}$. Tanggul dan dasarnya terbuat dari tanah lempung berpasir, lebar tanggul utama $\pm 1,5 \mathrm{~m}$ dengan dasar tambak sedikit miring kearah pembuangan air.

Bentuk petak tendon yang digunakan adalah empat persegi panjang luas $\pm 220 \mathrm{~m} 2$. Ukuran petak tendon tersebut masuk sangat kecil jika dibendingkan dengan luas petak pemeliharaan. Ukuran ideal petak tendon ini adalah $30-50 \%$ dari luas petak pemeliharaan. Kecilnya petak tendon yang dipergunakan tsb dikarenakan dalam penelitian aksi ini prinsipnya adalah menggunakan petak-petak yang sudah tersedia, sebab apabila akan merubah bentuk dan ukuran petak-petak yang ada dan disesuaikan dengan teknologi, maka akan memerlukan waktu yang lama dan biaya yang sangat besar. Disain tataletak tambak pola tradisional dengan SI-PBR secara lengkap disajikan pada Lampiran 1.

\section{Persiapan Tambak}

Persiapan tambak dimulai dengan pengeringan tanah hingga kering selama sekitar satu bulan, kemudian dilakukan pengapuran dosis 1 ton/ha dan pembalikan tanah (penyingkalan) yang dilanjutkan dengan pemberantasan hama dan penyakit dengan menggunakan THIODAN. Pupuk yang digunakan adalah urea dan TSP dengan dosis masing-masing 200 dan 100 $\mathrm{kg} / \mathrm{ha}$. Perbaikan tanggul dan kedhok teplok dilakukan untuk menutup kebocoran dan perembesan air, kemudian dilanjutkan dengan pembuatan caren, pembersihan kotoran dan pengaturan kemiringan lantai sehingga memudahkan dalam sirkulasi air.

\section{Pembuatan Tandon Filter Biologi Ikan Bandeng}

Pembuatan tendon filter biologis juga diawali kegiatan seperti pada persiapan petak pemeliharaan. Filter biologis yang digunakan adalah ikan bandeng dengan padat penebaran 5 ekor/m2. Pada kegiatan ini digunakan 1.250 ekor bandeng. Pengisian air dilakukan dua minggu sebelum dimasukkan ke petak pemeliharaan udang windu. Fungsi ikan bandeng adalah untuk memanfaatkan biomassa fitoplankton dan bahan terurai yang melimpah, mendaur ulang nutrient dan menjaga perkembangan fitoplankton agar stabil, dan untuk mengurangi beban lingkungan yang berasal dari partikel organic dan nutrien dalam air limbah. Pengairan petak pemeliharaan dilmulai dari pemasukan air dari petak tandon, dimasukkan ke petak pemeliharaan dengan melalui pintu dari kayu. Imunostimulan yang digunakan ada.lah imunostimulan dari Zoothamnium penaei yang dapat meningkatkan daya tahan tubuh terhadap serangan penyakit. Imunostimulan ini digunakan untuk benur udang sebelum ditebar, dengan cara direndam dengan dosis 300 mikrogram per liter

\section{Penyediaan Benih}

Penebaran benih dilakukan setelah air dalam petak pemeliharaan mencapai ketinggian $\pm 60 \mathrm{~cm}$ dan sudah didiamkan selama dua hari ( \pm 48 jam). Benih yang ditebar dapat berupa benur (PL-11) ataupun yang sudah berukuran glondongan. Penggunaan imunostimulan dilakukan pada tiap-tiap kantong plastik pada saat pengepakan untuk transportasi dengan dosis tiga tetes per kantong. Untuk kegiatan ini digunakan benih yang berukuran glondongan dan diambil dari pengusaha glondongan di sekitar lokasi penelitian. Hal ini bertujuan untuk mengurangi tingkat stress benih, karena 
kondisi perairan yang tidak terlalu jauh berbeda. Dua hari sebelum benih ditebar dilakukan pemberian biocyn pada air tambak dengan dosis $1 \mathrm{~kg} / \mathrm{ha}$, yang bertujuan untuk menjaga kualitas air selama pemeliharaan. Untuk selanjutnya biocyn diberikan tiap dua minggu sekali, dengan dosis $1 \mathrm{~kg} / \mathrm{ha}$. Penebaran benih udang dilakukan pada pagi hari, dengan padat tebar 16 rean/ha.

\section{Sirkulasi Air}

Sirkulasi air dilakukan setelah udang berumur satu bulan di petak pemeliharaan, dengan tujuan untuk mengurangi stress udang. Sirkulasi dilakukan dengan cara tiap hari mengurangi sebanyak $10-20 \%$ dikeluarkan melalui pintu pengeluaran. Sambil mengeluarkan air pemasukan air dari petak tandon juga dilakukan sebanyak air yang dikeluarkan. Sirkulasi air ini ditujukan untuk menggantikan air agar air selalu dalam keadaan baik dan bersih serta sebagai pengganti aerasi yang umumnya dengan menggunakan kincir air. Arah sirkulasi air ini disajikan pada Lampiran 1 dan hasil lengkap pemantauan kualitas air pada tambak disajikan pada Tabel 1.

Tabel 1. Hasil Rata-rata Pemeriksaan Parameter Kualitas Air selama Pemeliharaan Udang

\begin{tabular}{lc}
\hline \multicolumn{1}{c}{ Parameter } & Kisaran Nilai \\
\hline Kecerahan ( Cm ) & $30-35$ \\
Suhu $\left({ }^{\circ} \mathrm{C}\right.$ ) & $27-32$ \\
Salinitas ( ppt ) & $13-21$ \\
pH & $7.5-8.5$ \\
Oksigen terlarut ( ppm ) & $4-6$ \\
Nitrit ( ppm ) & $2-5$ \\
Karbondioksida & $0.1-0.2$ \\
\hline
\end{tabular}

Tabel 1 menunjukkan bahwa parameter kualitas air tambak selalu dalam kisaran optimalisasi pertumbuhan udang. Hal ini menunjukkan bahwa petak tandon dengan filter biologis dari ikan bandeng dapat menghasilkan kualitas air yang optimal.

\section{Pengelolaan Pakan dan Pertumbuhan Udang}

Pakan yang digunakan adalah pakan buatan pabrik, diberikan sebanyak empat kali sehari (24 jam). Dosis dan ukuran pakan disajikan pada Tabel 2.

Tabel 2. Cara, Dosis dan Waktu Pemberian Pakan

\begin{tabular}{llcc}
\hline \multicolumn{1}{c}{ Ukuran Udang } & \multicolumn{1}{c}{ Jenis Pakan } & Dosis (\%) BB/hari & Waktu Pemberian \\
\hline PL 15 - PL 20 & Flake & $25-50$ & $4 \mathrm{x}$ \\
$<$ I gram & Crumble & $25-50$ & $4 \mathrm{x}$ \\
1 - 5 gram & Pelet $\Phi 1 \mathrm{~mm}$ & $25-50$ & $4 \mathrm{x}$ \\
$5-$ 6 gram & Pelet $\Phi 1.5 \mathrm{~mm}$ & $15-25$ & $4 \mathrm{x}$ \\
$11-15$ gram & Pelet $\Phi 2.5 \mathrm{~mm}$ & $8-15$ & $4 \mathrm{x}$ \\
$20-30$ gram & Pelet $\Phi 4 \mathrm{~mm}$ & $4-8$ & $4 \mathrm{x}$ \\
\hline
\end{tabular}

Pertumbuhan udang sejak awal hingga umur dua bulan relatif normal dan merata serta menunjukkan adanya peningkatan seperti disajikan pada tabel 3 . Pemantauan penyakit dilakukan setiap hari mulai udang berumur satu bulan di tambak, dengan melihat gejala klinis yang Nampak dan dengan pengambilan sampel. Selama pemeliharaan udang, tidak ditemukan adanya penyakit yang menyerang.

Tabel 3. Pertumbuhan Udang Selama Periode Pemeliharaan

\begin{tabular}{cc}
\hline Hari ke- & Berat (gram) \\
\hline 0 (PL- 25/30) & $0.03-0.35$ \\
20 & $1.7-1.9$ \\
40 & $9.0-9.3$ \\
\hline
\end{tabular}




\begin{tabular}{cc}
\hline 60 & $15.5-16.6$ \\
90 & $20-26$ \\
\hline
\end{tabular}

Padat penebaran bandeng adalah satu rean/ha, sehingga dalam penelitian ini bandeng yang ditebar sebanyak 5.000 ekor. Dalam hal ini bandeng berfungsi untuk memanfaatkan ganggang dan plankton yang berlimpah dan berfungsi sebagai filter biologis seperti pada petak tandon. Dengan sistem ini ternyata sangat efektif untuk menjaga kelangsungan hidup udang dan pertumbuhan udang menjadi normal kembali. Pertumbuhan udang pada umur 90 hari ukuran udang sudah mencapai 40 - 45 ekor per kilogram (size 40-45).

\section{Hasil Panen Udang dan Bandeng}

Panen udang dilaksanakan setelah udang berumur kurang lebih tiga bulan di tambak dan udang sudah mencapai size 35 - 40 ekor per kilogram. Hasil panen udang dari ke tiga petak pemeliharaan dapat dilihat pada Tabel 4. Tingkat keberhasilan dari penerapan teknologi ini sangat tergantung dari keadaan tambak, lokasi tambak dan iklim/musim. Adapun kendala yang harus dihadapi dalam penerapan teknologi ini antara lain adalah : terlalu kecilnya petak tandon, sulitnya mendapatkan benih (glondongan) yang bermutu dan bebas penyakit serta sulitnya menahan penularan penyakit dari petak pemeliharaan lain. Sedangkan faktorfaktor yang mendukung keberhasilan dari penerapan teknologi ini antara lain adalah adanya kerjasama yang baik antara peneliti, petambak, penduduk sekitar dan instansi terkait.

Tabel 4. Hasil Panen Udang Pada Petak Pemeliharaan

\begin{tabular}{cccc}
\hline No. & $\begin{array}{c}\text { Petak Pemeliharaan Udang } \\
\text { dengan SI-PBR } \\
(\text { Kg/Petak) }\end{array}$ & $\begin{array}{c}\text { Petak Pemeliharaan } \\
\text { Kontrol (Kg/Petak) }\end{array}$ & $\begin{array}{c}\text { Petak Pemeliharaan } \\
\text { Bandeng (Kg/Pertak) }\end{array}$ \\
\hline I. & 795 & 211 & 587 \\
II. & 803 & - & - \\
III. & 922 & - & - \\
Rerata & 840 & & \\
\hline
\end{tabular}

Berdasarkan Tabel 4 di atas menunjukkan bahwa hasil panen udang windu pada tiap-tiap berturut-turut 795, 803, $840 \mathrm{Kg}$ per Petak, dengan rata-rata $840 \mathrm{~kg}$ dan ikan Bandeng $587 \mathrm{Kg}$. Jika dibandingkan dengan hasil panen pada tambak di sekitar kegiatan yang menunjukkan bahwa tiap petak rata-rata adalah $210 \mathrm{Kg}$ per Petak. Hasil tersebut menunjukkan bahwa dengan menggunakan model budidaya udang pola tradisional plus dengan sistem SI-PBR dapat meningkatkan hasil panen dari $272.43 \mathrm{Kg}$. menjadi rata-rata $840 \mathrm{Kg}$ per petak dengan luas rata-rata $1 \mathrm{Ha}$. Jika dipersentasekan adalah sebesar $412 \%$.

Bertitik tolak dari hal-hal tersebut di atas maka model budidaya udang pola tradisional SI-PBR dengan filter dari bandeng sangat menguntungkan, karena walaupun juga terjadi serangan penyakit, tidak sampai mematikan dan masih dapat teratasi, tidak seperti tambak-tambak di sekitar tambak percontohan.

\section{Evaluasi Hasil Kegiatan Sosialisasi/Penyuluhan}

Evaluasi hasil sosialisasi/ penyuluhan yang dilakukan dengan cara mendatangi langsung pada petambak menunjukkan adanya peningkatan pengetahuan tentang model budidaya udang pola tradisional plus dengan SIPBR. Hal ini terbukti bahwa para petambak yang turut berperan serta dalam kegiatan ini sudah menerapkan pola tradisional plus dengan melakukan pengapuran dan pembuatan petak sirkulasi dengan filter biologi dengan ikan bandeng. 


\section{Pendampingan dan Pembinaan Penerapan SI-PBR}

Berdasarkan hasil penerapan metode SI-PBR menunjukkan adanya peningkatan hasil panen udang hingga 412\%. Hasil evaluasi setelah kegiatan pengabdian kepada masyarakat selesai menunjukkan bahwa terdapat 4 dari 20 petambak yang menerapkan SI-PBR pada pemeliharaan udang.

\section{KESIMPULAN DAN SARAN Kesimpulan}

1. Penerapan SI-PBR terbukti dapat meningkatkan daya tahan tubuh udang sehingga udang tidak terserang penyakit selama pemeliharaan.

2. Petak sirkulasi dengan filter biologis dari ikan bandeng dapat meningkatkan dan mempertahankan kualitas air tambak pemeliharaan udang, sehingga selalu kondisi yang optimal untuk kehidupan udang windu.

3. Model budidaya udang pola tradisional plus dengan SI-PBR dapat meningkatkan hasil panen udang windu hingga 412\%, sehingga dapat direkomendasikan untuk diperluas penerapannya pada di kecamatan Banyuates, sampan, Madura khususnya dan di Indonesia pada umumnya.

\section{Saran}

1. Untuk menerapkan model budidaya pola tradisional plus dengan SI-PBR disarankan minimum menggunakan 3 petakan yaitu satu petak untuk petak tandon dengan filter biologis ikan bandeng. Dua petak berikutnya adalah untuk petak pemeliharaan udang.

2. Perlu pemantauan terhadap kesehatan udang secara rutin dan kualitas air selama penerapan model budidaya udang pola tradisional plus SI-PBR untuk menjaga optimalisasi parameter kualitas air.

\section{DAFTAR PUSTAKA}

Aji, B., S. Ginting dan M. Cristina. 1998. Rezeki dari Si Bongkok. Kontan. No. 40. Tahun II.

Chifumi, Thongchai, Osamu \& Kurokura, 2005. Incentive to shifts in Water management systems by shrimp culturist in Shouthern Thailand, Fisheries Science, Vol 71, Issue 4, Pages 791-8

German, M, Eduardo U, Gasper S \& Elizabeth V.B, 2008. A Comparison of Larval production of the Nothern scallop, Argopertempurpuratus, in closed and recirculating Culture system, J.Aquaeng, Vol 38, 11.004.

Haryanti. 2004. Broodstock Udang Vannamei. Makalah pada Seminar Sehari Perudangan Nasional: Upaya Mengatasi Problem Teknis dan Pemasaran Udang Melalui Standarisasi Budidaya.

KKP, 2013. Strategi pengembangan perikanan budidaya dalam menghadapi daya saing, materi disampaikan pada Seminar Nasional BKPIM 2013.

Liao, I. C. 2000. Aquaculture Development: Challenges for the $21^{\text {st }}$ Century.

Maeda, M, K. Nogami \& Y. Kotami, 200. Manipualtion of microbiol communities for Improving the Aquaculture Environment, J.Aquaculture, 02.035 : 192-8

Mahasri, G., 2007. Kemampuan ikan Bandeng sebagai Filter Biologi dalam Menekan Pertumbuhan Ciliata Patogen pada Tambak, LPPM Universitas Airlangga, Surabaya.

Moss, S. M. and S. M. Arce. 2003. SPF Defined: Pathogen - Free Status of Shrimp Limited. Global Aquaculture Advocate. 
Rosati, R, 1994, Indonesian Shrimp Industry Status and Development Project, Puslitbang Perikanan, Jakarta.

Rosy, L.J, Valeriano, L.C.Jr \& Taizos, 2004. Water quality and phytoplankton Stability in Response to application frequency of Bioargumentation agent in Shrimp pond. In Press, Accepted Manuscript, Available on line Aquaculture Enginering doi 10.10. J.Aqua Eng.01.001 page :200-5

Rukyani, A, 1994, Jenis Penyakit Udang, Makalah Pertemuan Aplikasi Paket Teknologi Pertanian, BIP Lampung, 9 - 11 Januari 1994.

Sharift, M, F.M Yosoff, T.N Devaraja \& Srinivasan R, 2001. The Effectiveness of a commercial microbiol product in Poorly prepared tiger shrimp Penaeus monodon ponds, Aquaculture Research Vol 32 Issue $3: 181-7$

Subandriyo, 2001, Budidaya Udang dengan Sistem Resirkulasi dan Masalahnya, Pt. Charoen Pokphand Indonesia, Medan.

Supito, A. Taslihan dan M. Murdjani. 2004. Solusi Pencegahan White Spot pada Pembesaran Udang Windu di Tambak Sidoarjo dan Gresik Dengan Penerapan BMP Balai Besar Pengembangan Budidaya Air Payau

Syarief, H dan Faisol Humaidi, 2006, Budidaya Udang Air Payau Sistem Tradisi Berbasis Organik di Sidoarjo, Makalah Pertemuan Penerapan Teknologi BMP untuk Mendukung Revitalisasi Budidaya Udang, DKP - ACIAR, Surabaya 6 - 8 Maret 2006. Hal 1 - 20.

Taslihan, A, Supito, Erik Sutikno, R.B. Callinan, 2005, Teknik Budidaya Udang Secara Benar, Balai Besar Pengembangan Budidaya Air Payau, Ditjen Perikanan Budidaya, Jakarta.
Warta Pasar Ikan. 2005. Warta Pasar Ikan. Direktorat Jenderal Perikanan. Departemen Kelautan dan Perikanan. Jakarta.

Wu Xiongfei \& Z. Zhidong, 2005. Closed recirculating system for shrimpmoluscha polyculture, J.oceanolimno, Vol 24 No 4 : 461-8.

Yoram, A, 2006. Biofilters : The need for a new Comprehensive Approach, J.Aquaeng, Vol 34 : 172-8. 